\title{
Economic implications of brush treatments to improve water yield
}

\author{
KEITH L. OLENICK, J. RICHARD CONNER, R. NEAL WILKINS, URS P. KREUTER, AND WAYNE T. HAMILTON
}

Authors are Research Assistant, Department of Rangeland Ecology and Management, Texas A\&M University, College Station, Tex. 77843-2126; Professor, Department of Agricultural Economics, Texas A\&M University, College Station, Tex. 77843-2124; Associate Professor, Department of Wildlife and Fisheries Science, Texas A\&M University, College Station, Tex. 77843-2258; Assistant Professor, Department of Rangeland Ecology and Management, Texas A\&M University, College Station, Tex. 77843-2126; and Senior Lecturer, Department of Rangeland Ecology and Management, Texas A\&M University, College Station, Tex. 77843-2126.

Abstract

One possible method of increasing water yield in some waterpoor areas is through brush management. Economic modeling of brush control programs designed to improve water yield has been performed for numerous Texas watersheds. These studies assumed a single criteria brush control program. This single criteria program may have negative impacts on certain wildlife habitats, is likely unacceptable to landowners, and does not incorporate additional restoration practices. Our study analyzed the economic consequences of 3 brush management/restoration scenarios for the Edwards Aquifer recharge zone and Twin Buttes watersheds and the drainage basins contained within. Economic measures included total public cost (\$) and public cost of producing additional water $\left(\$ / 1000 \mathrm{~m}^{3}\right.$ of added water). Because of its larger size, estimated total public cost was higher for the Twin Buttes watershed than for the Edwards Aquifer recharge zone watershed, despite the fact that the Twin Buttes had lower cost per ha of treated brush. Public cost of additional water is lower for basins within the Edwards Aquifer recharge zone watershed (ranging from $\$ 26$ to $\$ 44$ per $1000 \mathrm{~m}^{3}$ of added water) than in the Twin Buttes watershed (ranging from $\$ 51$ to \$129) which suggests that public investment in brush management efforts are likely to be more economically efficient in the Edwards Aquifer area. Within individual basins, public cost of additional water were similar for all 3 brush management/restoration scenarios.

Key Words: Brush management, cost sharing, wildlife habitat, rangeland restoration, Edwards Aquifer, Twin Buttes Reservoir

By 2050 , existing water resources and new sources will only be able to meet $83.6 \%$ of Texas' estimated 25.84 billion $\mathrm{m}^{3}$ annual water demand (Lesikar et al. 1998) and water will become a severe limiting natural resource (TWDB 1997). Encroachment of woody plants in Texas over the last 100 years has reportedly altered the hydrologic functioning of rangelands with the infestation of brush lowering water yields compared with grassland savannas (Thurow and Hester 1997, Bednarz et al. 2000). The

\footnotetext{
The research reported in this publication was funded by the United States Army Corps of Engineers. We acknowledge the contributions of the Blackland Research Center (Texas Agriculture Experiment Station, Temple, Texas).

Manuscript accepted 20 Oct. 03.
}

\section{Resumen}

Un método posible del rendimiento creciente de agua en algunas áreas pobres es por la administración y manejo del matorral o monte. El modelo económico del programa de control del matorral diseñado para mejorar el rendimiento de agua se ha realizado para numerosas líneas divisorias de las aguas de Tejas (Texas watersheds). Estos estudios asumieron un solo programa de criterios del control del matorral. Solo este criterio puede tener los impactos negativos en ciertos habitantes de la fauna silvestre, es probablemente inaceptable para los hacendados, y no incorpora las prácticas adicionales de la restauración. Nuestro estudio analizó las consecuencias económicas de tres guiones del manejo y administración de la restauración del matorral para la zona de recarga del Acuífero Edwards (Edwards Aquifer) y líneas divisorias de las aguas Twin Buttes y para las palanganas de desagüe contenidas dentro de. Las medidas económicas incluyeron el costo público total $(\$)$ y el costo público de producir agua adicional $\left(\$ / 1000 \mathrm{~m}^{3}\right.$ de agua agregada). A causa de su tamaño más grande, el costo público total estimado fue más alto para la línea divisoria de las aguas Twin Buttes que para la línea divisoria de las aguas de la zona de recarga del Edwards Aquifer, a pesar del hecho que los Twin Buttes tuvieron el costo más bajo por ha de matorral tratado. El costo público de agua adicional es más bajo para las palanganas dentro de la línea divisoria de las aguas de la zona de recarga del Edwards Aquifer (recorren de $\$ 26$ a $\$ 44$ por $1000 \mathrm{~m}^{3}$ de agua agregada) que en la línea divisoria de las aguas Twin Buttes (recorren de \$51 a \$129) que sugiere esa inversión pública en esfuerzos de administración del matorral es probable ser más eficiente económicamente que en el anterior. Dentro de las palanganas individuales, el costo público de agua adicional fue semejante para la administración de los tres escenarios de la restauración matorrales.

concomitant increase in human population and thus demand for water has brought more attention to brush control as a method of increasing or at least maintaining water supplies. Depending on geologic structure, climate, and soil types, brush control may increase water yield (Blackburn 1983, Dugas et al. 1998, Thurow and Hester 1997, Wilcox 2002), potentially resulting in higher recharge of ground-water aquifers and surface water yields (Walker and Dugas 1998). However, initial and follow-up brush treatment costs are an obstacle to landowner participation in brush control programs. Acknowledging the relationship between 
brush cover and water yield, the State of Texas has appropriated funds to begin cost-share programs for large-scale brush management programs designed to augment water yields (TSL 1997).

This study focused on the Edwards Aquifer recharge zone watershed (hereafter referred to as Edwards) and the Twin Buttes watershed (Fig. 1). The Edwards Aquifer is a water-bearing limestone formation located in south-central Texas. Over 1.5 million people depend on the aquifer as a primary source of water with the city of San Antonio relying exclusively on its waters. The Edwards includes the Upper Frio, Sabinal, Seco, Hondo, and Medina basins and covers 357,896 ha. By contrast, the Twin Buttes Reservoir watershed, located in West Texas just south and west of San Angelo, consists of the Middle Concho River, Spring and Dove Creeks, and the South Concho River basins (Upper Colorado River Authority 2000) and covers 956,447 ha. The Twin Buttes Reservoir is the primary source of water for the City of San Angelo.

Several studies have explored the cost implications of brush control practices in Texas from a rancher perspective. Some have incorporated benefits in the form of increased water yield in the analysis. In 1998, Bach and Conner analyzed the economic implications of a brush control program in the North Concho watershed (Texas). They estimated cost for brush treatments and expected rancher benefit. Using expected gains in water yield resulting from brush control, they also estimated the cost of producing water.

Studies analyzing only the costs of brush control include that by Lee et al. (2001) and Schumann et al. (2001). Lee used a biophysical plant growth model to simulate forage production, stocking rates, and animal production for 4 representative ranches in the Edwards Plateau. Findings indicated a need for subsidies to ranchers in order for increases in livestock revenue to equal the cost of brush treatments. Schumann et al. (2001) used biophysical modeling to assess economic implications of prescribed burn treatments in South Texas. A stochastic analysis was used to determine increases in rancher income resulting from treatments, and findings indicated that revenues from increased grazing capacity outweighed the cost of prescribed burn treatments. Lee et al. (2001) and Schumann et al. (2001) did not estimate or incorporate into their work changes in water yield resulting from brush treatments.

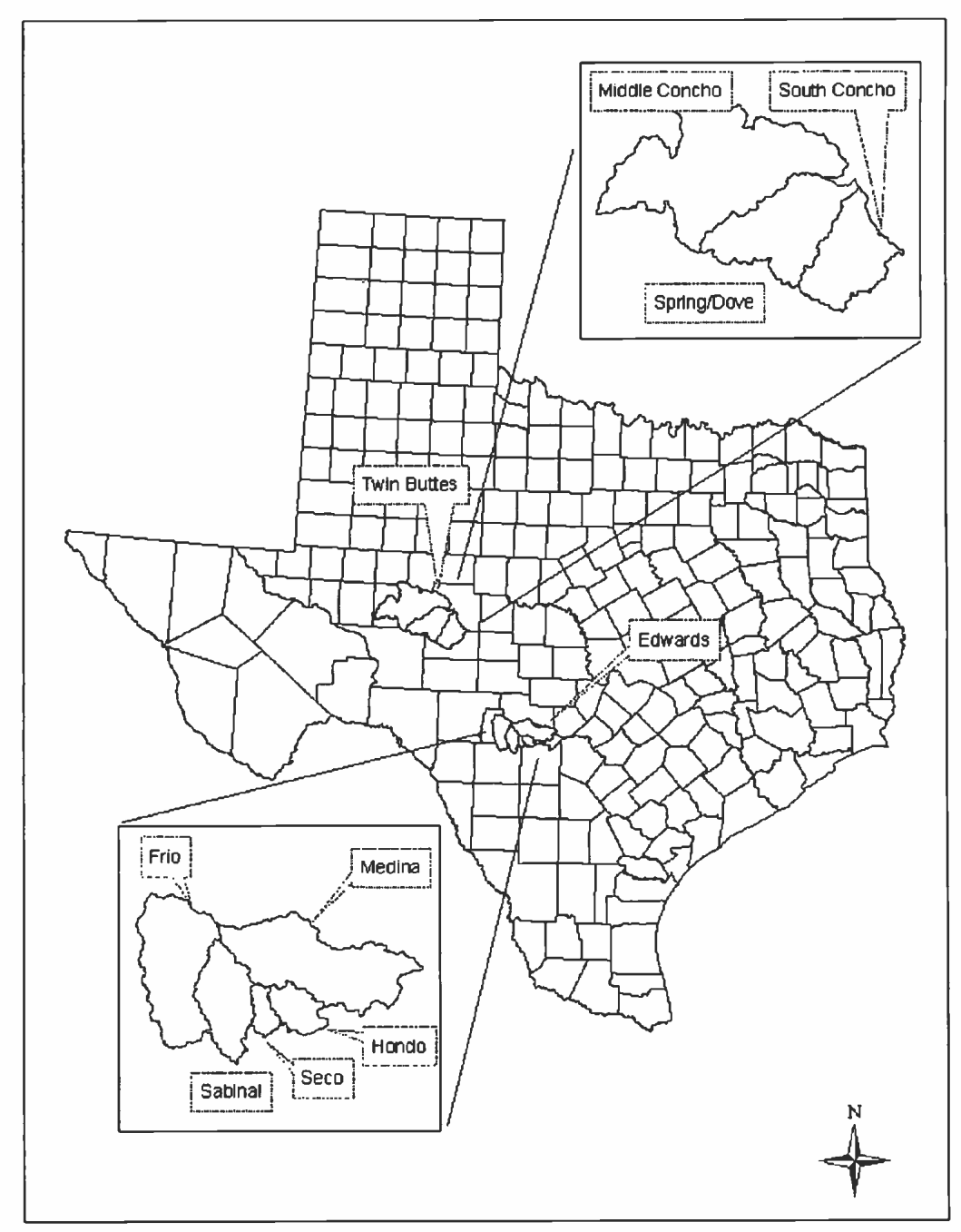

Fig. 1. Location of Edwards and Twin Buttes watersheds and associated drainage basins.

Lemberg et al. (2002) used plant growth, hydrologic, and economic models to determine costs and benefits (added water) resulting from brush control. The study area included parts of the Edwards Plateau and South Texas. Results indicated that net rancher returns resulting from brush control could be expected to be positive on a small percentage of the range sites studied.

A study investigating the hydrologic and economic impacts of a brush control program for the Edwards, Twin Buttes, and 6 other watersheds was completed in 2000 (Bednarz et al. 2000, Conner and Bach 2000). The study: 1) Estimated the potential change in stream flow of rivers and annual recharge to local underground aquifers (where applicable) under a single brush control plan, 2) Prioritized areas for brush control within watersheds by the amount of estimated steam flow and/or aquifer recharge, and 3) Estimated the costs of participation in such projects by private landowners and the state (Bednarz et al. 2000).
The brush control scenario used in the 2000 study called for the removal of all moderate (10-30\% canopy cover) and heavy ( $>30 \%$ canopy cover) categories of mesquite (Prosopis glandulosa Torr. var. glandulosa), juniper (Juniperus asheii Buckholtz, Juniperus pinchotii Sudh), and mixed brush, regardless of the land slope on which the brush was located. Initial and follow-up brush treatments were the only manipulation treatments assumed. This single brush control scenario would result in over $50 \%$ of land area being treated for the Edwards and Twin Buttes (Bednarz et al. 2000).

Negative impacts of such widespread uniform brush control can include loss of wildlife habitat due to fragmentation, thermal and/or escape cover, biodiversity, and food sources for wildlife (Rollins 2000). Such impacts could be especially harmful to whitetail deer (Odocoileus virginianus) and associated hunting enterprises (Fulbright 1997, Rollins et al. 1988). In addition, landowners may be reluctant to 
enroll significant portions of their brush in a brush management program that insists on widespread brush removal because of potentially adverse effects on property values (Tays 2001, Narayanan et al. 2002). Lastly, brush treatments occurring on sloped areas pose a significant erosion risk.

When coupled with other restoration practices, selective brush management can provide an opportunity to restore rangelands. For example, ecological restoration practices such as rangeland reseeding, grazing deferments, and rotational grazing systems can improve the quality of plant communities, thus improving hydrologic function and wildlife habitats (Hanselka et al. 1988, Welch and Anderson 1993).

In this paper, we calculate the economic implications of 3 brush management and restoration treatment scenarios that differ with respect to the amount and location of brush removal and incorporate various restoration actions. We used a deterministic model, similar to that used by Bach and Conner (1998) and Conner and Bach (2000), that incorporates information from hydrologic modeling, landowner focus group meetings, and expert opinions from range scientists. The results of our study allow basins and/or watersheds to be given priority ranking assuming public expenditures for a cost-share brush program and allow comparisons to be performed for different brush treatment scenarios.

\section{Methodology}

Three different sets of assumptions are used for the 2 study watersheds -1 for the Twin Buttes and 2 for the Edwards. Geographic differences between the eastern and western portions of the Edwards, including steeper slopes, shallower soils, and different animal enterprises in the Western portion, required the use of separate brush management and restoration treatments (hereafter referred to as brush treatments), carrying capacity, and livestock enterprise assumptions.

\section{Brush Treatment Scenarios}

Three brush treatment scenarios were identified with the help of wildlife and range scientists. To delineate these scenarios, Landsat images were used to identify $30 \mathrm{~m} \times 30 \mathrm{~m}$ pixels with $10-30 \%$ canopy cover (moderate cover) and greater than $30 \%$ canopy cover (heavy cover). In
Scenario I, all moderate and heavy categories of mesquite, juniper, and mixed brush were controlled with initial and follow-up treatments but no oak species were treated. Rangeland reseeding and yearlong grazing deferments were included as an integral part of mechanical treatments. The addition of a cross-fence was also assumed for treated areas. One constraint of Scenario I, and a key difference between this scenario and the brush management program used for the 2000 feasibility studies (Bednarz et al. 2000), is that no brush occurring on slopes $>15 \%$ is controlled due to machinery limitations and soil erosion concerns.

Scenario II is similar to Scenario I except that brush occurring within $75 \mathrm{~m}$ of all mapped streams was also excluded to protect riparian areas. Finally, Scenario III was similar to Scenario II except that the percentage of moderate and heavy brush cover remaining after brush control was at least $40 \%$ in each sub-basin located within 2 study watersheds. In sub-basins where the amount of treated area had to be reduced from Scenario II to arrive at the $40 \%$ threshold, treated areas of targeted brush type-density categories were reduced in equal proportions. The added constraints of Scenarios II and III simulate the landscape-level effects of maintaining important habitats for selected wildlife (e.g. white-tailed deer). Table 1 summarizes the brush treatment scenario differences. mixed brush that would be maintained for the 10 year planning horizon. Costs of initial brush treatments ranged from $\$ 64$ per ha for chemical control of moderate and heavy mesquite in the Twin Buttes watershed to $\$ 457$ per ha for mechanical treatments of heavy mesquite and heavy mixed brush in the eastern portion of the Edwards. Follow-up brush treatments included individual plant herbicide treatments or prescribed burning in years 3 and 7 after the initial treatments.

The restoration treatments incorporated for both study watersheds included native grass reseeding, grazing deferments, and improved grazing systems. Rangeland reseeding was considered feasible only when an adequate seedbed is prepared, i.e., where mechanical brush treatments were prescribed. In the reseeded areas, 1 year grazing deferments were imposed to facilitate the success of the seeding. To allow for the implementation of improved grazing systems, ranch infrastructure enhancements in the form of 1 additional cross fence and 1 additional water source were assumed for every 351 and 1,828 ha of combined moderate and heavy brush in the Edwards and Twin Buttes, respectively, which represent the average ranch sizes in those study areas (Narayanan et al. 2002). For some brush type-density categories, several sets of brush treatments were appropriate. In these instances, each of the different sets of treatments were assumed to be implemented in equal proportion.

Table 1. Brush management/restoration scenario descriptions.

\begin{tabular}{cccccc}
\hline \hline & \multicolumn{5}{c}{ Treatment Constraint Parameters } \\
\cline { 2 - 6 } & $\begin{array}{c}\text { Reseeding, Grazing } \\
\text { Deferment, } \\
\text { Scenio }\end{array}$ & $\begin{array}{c}\text { Brush on } \\
\text { Treated }\end{array}$ & $\begin{array}{c}\text { Slopes }>15 \% \\
\text { Protected }\end{array}$ & $\begin{array}{c}\text { 40\% Residual } \\
\text { Moderate and } \\
\text { Heavy Brush }\end{array}$ & $\begin{array}{c}\text { 75m Riparian } \\
\text { Buffer Zone }\end{array}$ \\
\hline 2000 Study & $\mathrm{X}$ & $\mathrm{X}$ & $\mathrm{X}$ & \\
I & $\mathrm{X}$ & $\mathrm{X}$ & $\mathrm{X}$ & $\mathrm{X}$ & \\
II & $\mathrm{X}$ & $\mathrm{X}$ & $\mathrm{X}$ & $\mathrm{X}$ & $\mathrm{X}$ \\
III & $\mathrm{X}$ & & & & \\
\hline
\end{tabular}

\section{Brush Treatments}

Initial brush treatments considered included tree dozing with raking, tree shearing followed by fire, excavation (use of large back-hoe that digs out or "excavates" plants) followed by fire, rootplowing following by raking, stacking and burning, low-energy grubbing, and aerially applied herbicide. Brush control treatments were expected to result in brush canopy of 3-8\% for moderate and heavy juniper and mesquite, $30-35 \%$ for heavy mixed brush, and $8-12 \%$ for moderate

\section{Livestock/Wildlife Assumptions and Enterprises}

Increased herbaceous production following brush control and restoration treatments can enhance carrying capacity and potential rancher income (Reinecke et al. 1997, Whitson et al. 1984). Initial carrying capacity figures ranged from 28.3 ha per animal unit (AU) in the Twin Buttes for heavy cedar to 10.1 ha per AU in the eastern and western portions of the Edwards for moderate mesquite. Year 9 carrying 
capacity figures were lowest for moderate and heavy cedar in the Twin Buttes at 11.8 ha per AU and highest for heavy and moderate mesquite in the Eastern and Western regions of the Edwards at 6.8 ha per AU. Our analysis assumed that ranchers would increase livestock numbers to meet the increased capacity resulting from brush treatments.

Livestock and wildlife enterprise assumptions considered for the eastern and western Edwards, and Twin Buttes were similar to those used in the 2000 studies (Bach and Conner 2000a, 2000b). Specifically, livestock enterprise operation types used included $80 \%$ cow-calf $/ 20 \%$ meat goat for the eastern Edwards, $20 \%$ cow-calf $/ 50 \%$ meat goat $/ 40 \%$ sheep for the western Edwards, and $60 \%$ cow-calf/ $10 \%$ meat goat $30 \%$ sheep for the Twin Buttes. Sales prices, sales weight, reproductive rates, and variable costs varied depending on the region and livestock type but were constant during the 10 year investment horizon.

Partial revenues (increased yearly revenues derived from increased numbers of stock) consisted of the sale of calves, kids, lambs, and wool. In addition, revenue was realized in the last year of the program (year 9) from the salvage of cows, bulls, nannies, billies, ewes and rams. Partial costs included the purchase price of cows, bulls, nannies, billies, ewes and rams and variable costs attributed to cow/calf, nannie/kid, and ewe/lamb pairs. These variable costs items included supplemental feed, salt and minerals, marketing, veterinary medicine, shearing (sheep), miscellaneous, and net replacement of female and male animals.

Based on previous studies, increases in wildlife net income would only be realized for the control of heavy brush (Bach and Conner 2000a, 2000b). The increases are attributed to improved deer (Edwards and Twin Buttes) and quail (Twin Buttes) habitat.

We defined total rancher benefit of brush treatments for each brush type-density as the sum of discounted net incomes from livestock and wildlife operations.

\section{Water Yield}

The Soil and Water Assessment Tool (SWAT), originally designed to model non-point source pollution by USDAAgriculture Research Service, was used in this study to estimate increases in stream flow at the sub-basin level following brush removal (Bednarz et al. 2000). Specifically, researchers at the Blackland Research Center (Texas Agriculture Experiment Station, Temple, Texas) used SWAT to simulate water yield in the 2 study areas for the period 1960 through 1998. From the estimated total 39-year (1960-1998) added water total, an average yearly amount was calculated. Because discounting water yields is commonly practiced for analyzing water projects (Griffin and Chowdury 1993, Rister et al. 2002), we discounted the added water estimates for each year of our investment horizon to ensure that potential benefits of brush treatments are not overstated compared with costs. Discounting water yields recognizes that public entities funding water projects (in this case, brush treatments) could potentially invest those monies in interest-earning investments. The 2003 discount rate mandated for federally-funded water projects is $5.875 \%$ (The Natural Resources Inventory and Analysis Institute, http://waterhome.brc.tamus.edu, 2003). We used a discount rate of $6 \%$ when discounting future water yields. Table 2 shows the estimated 10-year discounted water yields for each basin.

\section{Economic Analysis}

For the economic analysis, we used a 10 year planning horizon and a $6 \%$ discount rate as the opportunity cost of rancher capital. In addition, we used estimated rancher benefits of brush treatments as a measure of landowner's cost-share. One major premise of this model is that landowners would only be willing to pay for the portion of brush control costs up to the benefits they would receive from brush treatments. Based on this, public's cost-share is equal to the present value of brush treatment cost minus the estimated landowner benefits.
Our analytical model incorporates a partial budget to estimate costs and benefits. Incremental increases in stocked animal units for each year of the brush program caused by brush treatments for each targeted brush-type density were evaluated. The total public cost of the 3 scenarios was calculated by multiplying the public costshare per ha of each brush type-density category by the estimated area of brush cleared in each category. Thus, total public cost can be thought of as the theoretical cost of implementing brush treatment scenarios by an external funding source. Cost of added water was calculated by dividing total public cost by the discounted 10-year added water yield. This measure represents the economic efficiency of water production associated with brush clearing. Public cost per ha of treated brush was determined by dividing total public cost by the number of ha treated and is a function of the abundance of each brush category and treatment costs.

\section{Results}

\section{Public/Landowner Cost-Shares}

Total brush treatment discounted 10year costs for the different brush type-densities in the 2 study areas ranged from a low of $\$ 128$ per ha for chemical control of heavy mesquite in the Twin Buttes to a high of $\$ 679$ per ha for rootplow with predoze treatment of heavy mesquite in the eastern Edwards (Tables 3, 4, and 5). For all brush type-densities in the 2 Edwards study areas and the Twin Buttes, landowner cost-share never comprised more than $40 \%$ of total treatment cost meaning that added livestock/wildlife income resulting from brush control/restoration practices were much less than treatment costs for the 10-year project horizon.

\section{Area Treated}

Because the extent of brush control affects both the water yield and expense of cost-share brush programs, the area of brush treated under each of the 3 scenarios

Table 2. Total 10-year added water $\left(x 1000 \mathrm{~m}^{3}\right)$ discounted at $6 \%$ for all basin/scenario combinations.

\begin{tabular}{|c|c|c|c|c|c|c|c|c|c|c|}
\hline & \multirow[b]{2}{*}{ Frio } & \multicolumn{4}{|c|}{ Edwards } & \multicolumn{5}{|c|}{ Twin Buttes } \\
\hline & & Hondo & Medina & Sabinal & Seco & Total & $\begin{array}{l}\text { Middle } \\
\text { Concho }\end{array}$ & $\begin{array}{l}\text { South } \\
\text { Concho }\end{array}$ & $\begin{array}{c}\text { Spring- } \\
\text { Drive }\end{array}$ & Total \\
\hline Scenario I & 307,391 & 153,065 & 957,326 & 199,584 & 37,665 & $1,655,030$ & 351,741 & 294,116 & 368,206 & $1,014,063$ \\
\hline Scenario II & 242,205 & 128,240 & 797,421 & 162,643 & 36,926 & $1,367,435$ & 333,796 & 282,291 & 350,693 & 967,050 \\
\hline Scenario III & 235,393 & 124,651 & 765,649 & 156,947 & 36,926 & $1,319,566$ & 146,104 & 115,884 & 147,316 & 409,304 \\
\hline
\end{tabular}


Table 3. Landowner and public cost-shares for targeted brush type-density categories-eastern Edwards (80\% cow/calf - $20 \%$ meat goat).

\begin{tabular}{|c|c|c|c|c|c|c|}
\hline \multirow{2}{*}{ Brush Type/Category } & \multirow{2}{*}{$\begin{array}{l}\text { Control } \\
\text { Practice }\end{array}$} & Total Cost & \multicolumn{2}{|c|}{ Rancher Share } & \multicolumn{2}{|c|}{ Public Share } \\
\hline & & (\$/ha) & (\$/ha) & & (\$/ha) & \\
\hline Heavy Cedar & Shear & 626.79 & 78.8 & $12.57 \%$ & 547.99 & $87.43 \%$ \\
\hline \multirow{4}{*}{ Heavy Mesquite } & Chemical & 227.31 & 83.84 & $36.88 \%$ & 143.47 & $63.12 \%$ \\
\hline & Rootplow & 617.38 & 94.81 & $15.36 \%$ & 522.56 & $84.64 \%$ \\
\hline & Rootplow & & & & & \\
\hline & with Pre-doze & 679.15 & 94.81 & $13.96 \%$ & 584.34 & $86.04 \%$ \\
\hline \multirow[b]{2}{*}{ Heavy Mixed Brush } & Rootplow & 578.74 & 83.94 & 14.50 & 494.8 & $85.50 \%$ \\
\hline & $\begin{array}{l}\text { Rootplow } \\
\text { with Pre-doz }\end{array}$ & 640.52 & 83.94 & $13.11 \%$ & 556.58 & $86.89 \%$ \\
\hline Moderate Cedar & $\begin{array}{l}\text { Doze or } \\
\text { Shear }\end{array}$ & 430.48 & 33.9 & $7.88 \%$ & 396.58 & $92.12 \%$ \\
\hline \multirow[t]{2}{*}{ Moderate Mesquite } & $\begin{array}{l}\text { Chemical } \\
\text { Mechanical }\end{array}$ & 227.31 & 25.77 & $11.34 \%$ & 201.54 & $88.66 \%$ \\
\hline & Choice & 336.04 & 33.7 & $10.03 \%$ & 302.33 & $89.97 \%$ \\
\hline Moderate Mixed Brush & $\begin{array}{l}\text { Mechanical } \\
\text { Choice }\end{array}$ & 333.21 & 35.21 & $10.57 \%$ & 298.00 & $89.43 \%$ \\
\hline
\end{tabular}

Table 4. Landowner and public cost-shares for targeted brush type-density categories-western Edwards (20\% cow/calf $-50 \%$ meat goat-30\% sheep).

\begin{tabular}{|c|c|c|c|c|c|c|}
\hline \multirow{2}{*}{ Brush Type/Category } & $\begin{array}{l}\text { Control } \\
\text { Practice }\end{array}$ & Total Cost & \multicolumn{2}{|c|}{ Rancher Share } & \multicolumn{2}{|c|}{$\underline{\text { Public Share }}$} \\
\hline & & $(\$ / h a)$ & $(\$ / \mathrm{ha})$ & & (\$/ha) & \\
\hline & Two Way Chain & 442.29 & 65.88 & $14.89 \%$ & 376.41 & $85.11 \%$ \\
\hline \multirow[t]{2}{*}{ Heavy Cedar } & Tree Doze & 578.19 & 65.88 & $11.39 \%$ & 512.32 & $88.61 \%$ \\
\hline & Flat Cutting & 541.13 & 65.88 & $12.17 \%$ & 475.25 & $87.83 \%$ \\
\hline \multirow{3}{*}{ Heavy Mesquite } & Chemical & 227.31 & 68.87 & $30.30 \%$ & 158.44 & $69.70 \%$ \\
\hline & Rootplow & 606.2 & 76.08 & $12.55 \%$ & 530.12 & $87.45 \%$ \\
\hline & Pre-doze & 667.97 & 76.08 & $11.39 \%$ & 591.89 & $88.61 \%$ \\
\hline Heavy Mixed Brush & Tree Doze & 579.43 & 71.36 & $12.32 \%$ & 508.07 & $87.68 \%$ \\
\hline \multirow{3}{*}{ Moderate Cedar } & Tree Doze & 418.81 & 37.63 & $8.99 \%$ & 381.18 & $91.01 \%$ \\
\hline & Tree Shear or & & & & & \\
\hline & Flat Cutting & 369.39 & 37.63 & $10.19 \%$ & 331.76 & $89.81 \%$ \\
\hline \multirow{2}{*}{ Moderate Mesquite } & Chemical & 227.31 & 22.26 & $9.79 \%$ & 205.05 & $90.21 \%$ \\
\hline & Choice & 336.04 & 29.68 & $8.83 \%$ & 306.36 & $91.17 \%$ \\
\hline Moderate Mixed Brush & $\begin{array}{l}\text { Mechanical } \\
\text { Choice }\end{array}$ & 333.21 & 30.15 & $9.05 \%$ & 303.07 & $90.95 \%$ \\
\hline
\end{tabular}

Table 5. Landowner and public cost-shares for targeted brush type-density categories-Twin Buttes (60\% cow/calf $-10 \%$ meat goat $-30 \%$ sheep).

\begin{tabular}{|c|c|c|c|c|c|c|}
\hline \multirow{2}{*}{ Brush Type/Category } & \multirow{2}{*}{$\begin{array}{l}\text { Control } \\
\text { Practice }\end{array}$} & Total Cost & \multicolumn{2}{|c|}{ Rancher Share } & \multicolumn{2}{|c|}{ Public Share } \\
\hline & & (\$/ha) & (\$/ha) & & (\$/ha) & \\
\hline Heavy Cedar & Doze or Shear & 351.41 & 35.68 & $10.15 \%$ & 315.73 & $89.85 \%$ \\
\hline Heavy Mesquite & $\begin{array}{l}\text { Chemical } \\
\text { Mechanical }\end{array}$ & 127.96 & 32.79 & $25.63 \%$ & 95.17 & $74.37 \%$ \\
\hline & Choice & 354.38 & 37.07 & $10.46 \%$ & 317.32 & $89.54 \%$ \\
\hline Heavy Mixed Brush & $\begin{array}{l}\text { Mechanical } \\
\text { Choice }\end{array}$ & 315.76 & 35.34 & $11.19 \%$ & 280.42 & $88.81 \%$ \\
\hline Moderate Cedar & $\begin{array}{l}\text { Mechanical } \\
\text { Choice }\end{array}$ & 241.44 & 21.92 & $9.08 \%$ & 219.52 & $90.92 \%$ \\
\hline Moderate Mesquite & $\begin{array}{l}\text { Chemical } \\
\text { Mechanical }\end{array}$ & 146.55 & 15.52 & $10.59 \%$ & 131.03 & $89.41 \%$ \\
\hline & Choice & 263.00 & 21.97 & $8.35 \%$ & 241.03 & $91.65 \%$ \\
\hline Moderate Mixed Brush & $\begin{array}{l}\text { Mechanical } \\
\text { Choice }\end{array}$ & 242.86 & 19.79 & $8.15 \%$ & 223.07 & $91.85 \%$ \\
\hline
\end{tabular}

is presented first (Table 6). The estimated amount of treated area for the Twin Buttes was greater than that in the Edwards under all scenarios; the percentage differences between the Twin Buttes and the Edwards were $224 \%, 269 \%$, and $52 \%$ for Scenarios I, II, and III, respectively. The Edwards showed larger differences in total treated area between Scenarios I and II than between Scenarios II and III. In contrast, the Twin Buttes showed very minor differences between Scenarios I and II and substantial differences in total treated area between Scenarios II and III. These differences are explained by the fact that the oak and slope constraints helped satisfy the $40 \%$ residual brush requirement of Scenario III in the Edwards but accounted for very little of that residual brush requirement for Scenario III in the Twin Buttes.

For the Edwards' basins, the difference between area treated under Scenario I and Scenario III ranged from $20 \%$ to $33 \%$ (Hondo and Frio basins, respectively). Differences between Scenarios I and II were greater (Hondo $=17 \%$ and Frio $=$ $24 \%$ ) than differences between Scenarios II and III (Hondo $=2 \%$ and Frio $=7 \%$ ). These differences can also be explained by the fact that oak and all brush occurring on slopes exceeding $15 \%$ accounted for much of the $40 \%$ residual brush requirement under Scenario III.

In contrast to the Edwards study area, the difference in total treated area between Scenarios I and III ranged from $155 \%$ (Spring/Dove Creeks, South Concho) to 183\% (Middle Concho) (Table 6). The percentage difference between Scenarios I and II averaged $5 \%$ for all basins while the percentage difference between Scenarios II and III averaged $156 \%$ for the 3 Twin Buttes' basins. The cause of this difference is also due to the oak and slope constraints.

\section{Total Public Cost}

To prioritize public investments, it is necessary to determine total public cost of brush treatment programs in each drainage basin. Total public cost is a function of the amount of brush treated and the cost per unit area treated. In comparing cost per area of brush treated for the 2 watersheds, the Edwards' basins were about twice as expensive to treat per ha because of the higher expense associated with clearing brush on the rougher terrain found in the Edwards (Fig. 2). While the cost of implementing Scenario I was $26 \%$ more costly than Scenario III in the Edwards, the per- 


\begin{tabular}{|c|c|c|c|c|c|c|c|c|c|c|}
\hline & \multicolumn{6}{|c|}{ Edwards } & \multicolumn{4}{|c|}{ Twin Buttes } \\
\hline & Frio & Hondo & Medina & Sabinal & Seco & Total & $\begin{array}{l}\text { Middle } \\
\text { Concho }\end{array}$ & $\begin{array}{l}\text { South } \\
\text { Concho }\end{array}$ & $\begin{array}{l}\text { Spring- } \\
\text { Drive }\end{array}$ & Total \\
\hline Scenario I & 30,351 & 8,617 & 59,063 & 17,128 & 3,535 & 118,694 & 204,986 & 69,306 & 110,322 & 384,614 \\
\hline Scenario II & 24,389 & 7,369 & 50,144 & 14,258 & 2,876 & 99,037 & 194,956 & 65,905 & 104,790 & 365,651 \\
\hline Scenario III & 22,741 & 7,198 & 47,980 & 13,572 & 2,876 & 94,366 & 72,525 & 27,208 & 43,294 & 143,027 \\
\hline$\%$ Difference I & & & & & & & & & & \\
\hline to III & $33 \%$ & $20 \%$ & $23 \%$ & $26 \%$ & $23 \%$ & $26 \%$ & $183 \%$ & $155 \%$ & $155 \%$ & $169 \%$ \\
\hline $\begin{array}{l}\text { \% Difference II } \\
\text { to III }\end{array}$ & $7 \%$ & $2 \%$ & $5 \%$ & $5 \%$ & $0 \%$ & $5 \%$ & $169 \%$ & $142 \%$ & $142 \%$ & $156 \%$ \\
\hline $\begin{array}{l}\text { \% Difference I } \\
\text { to II }\end{array}$ & $24 \%$ & $17 \%$ & $18 \%$ & $20 \%$ & $23 \%$ & $20 \%$ & $5 \%$ & $5 \%$ & $5 \%$ & $5 \%$ \\
\hline
\end{tabular}

centage difference is a substantially higher $167 \%$ in the Twin Buttes (Fig. 3). This difference was due to the $40 \%$ residual brush requirement of Scenario III being reached in the Edwards with the slope and oak retention constraints. Total public costs were higher in the Twin Buttes than the Edwards for Scenarios I and II. Despite the fact that less brush was treated under Scenario III in the Edwards than the Twin Buttes, total treatment cost for this scenario was $\$ 10.2 \mathrm{M}$ greater in the Edwards because of its much higher cost per treated ha.

For all basins in both study areas, Scenario I was the most expensive to implement followed by Scenarios II and, lastly, Scenario III. For the Edwards, total public cost was highest for the Medina and lowest for the Seco basins (Fig. 3). It should be noted that the large differences between the Medina and Seco were the result of differences in the amount of treated brush and not the cost of those treatments; in the Edwards basins, estimated brush treatment costs per ha were greatest in the Seco basin (Fig. 2).
In the Twin Buttes' basins, estimated total public costs were lowest for the South Concho basin. When analyzed on a dollars per treated ha basis (Fig. 2), all Twin Buttes' basins exhibit very similar costs of brush and restoration treatments indicating total public costs in the Twin Buttes are mainly a function of area requiring treatment in each basin. Consequently, larger basins such as the Middle Concho and Spring/Dove Creeks showed highest costs to implement the 3 scenarios (Fig. 3).

\section{Public Cost of Added Water}

Estimates of the public cost of adding $1000 \mathrm{~m}^{3}$ of water through brush removal provide a measure of relative efficiency of using public funds to control brush for increased water yield. The Edwards watershed and its basins had much lower costs of added water for any chosen brush treatment scenario. Compared with the Edwards, cost of added water for the entire Twin Buttes study area were $163 \%$ higher for Scenario I, $160 \%$ higher for Scenario II, and $144 \%$ higher for Scenario

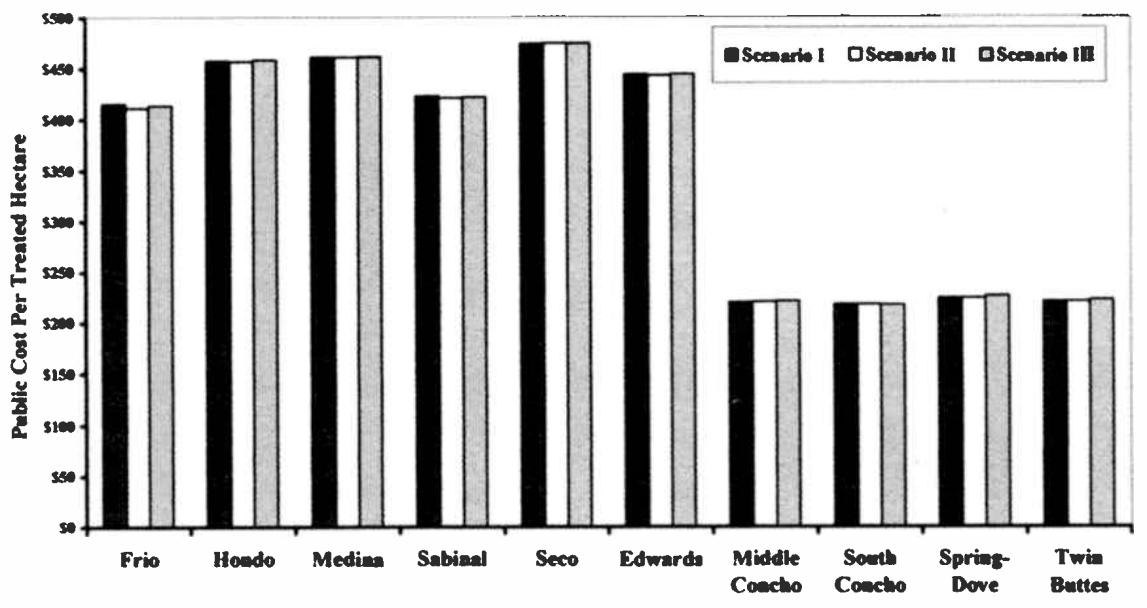

Fig. 2. Public cost per treated hectare of brush in Edwards and Twin Buttes watersheds.
III (Fig. 4). The cause of this variation is attributed to the different water-generation characteristics of vegetation/soils and differences in climate included in the SWAT analysis and different brush treatment costs in the 2 study areas. When viewed individually, both watersheds had similar cost of added water for all 3 scenarios. Similarities are explained by the fact that water yield output estimates from SWAT modeling assumed a constant relationship between amount of brush treated and water yield.

In the Edwards, cost of added water for Scenarios I, II, and III ranged from \$26 per $1000 \mathrm{~m}^{3}$ of water added (Hondo, all scenarios) to $\$ 44$ (Seco, Scenario I) (Fig. 4). However, for individual Edwards basins public cost of added water was similar for all scenarios except the Seco.

In the Twin Buttes basins, the estimated costs were highest for the Middle Concho at between $\$ 110$ (Scenario III) and \$129 per $1000 \mathrm{~m}^{3}$ of water added (Scenario II). The least expensive cost of added water would be realized by brush control in the South Concho ( $\$ 51$ per $1000 \mathrm{~m}^{3}$ for all scenarios) because of its improved hydrologic conditions.

\section{Discussion}

Our study indicated that the total public cost for brush treatments aimed at increasing water yield was higher for the Twin Buttes than the Edwards. While all brush treatment scenarios exhibited similar total public cost in the Edwards, Scenario III was substantially less expensive in the Twin Buttes. Constraints on available public funds could therefore result in the exclusion of Scenarios I and II in the Twin Buttes basins. However, the Twin Buttes' basins are much cheaper to treat on a dollars per treated area basis. 

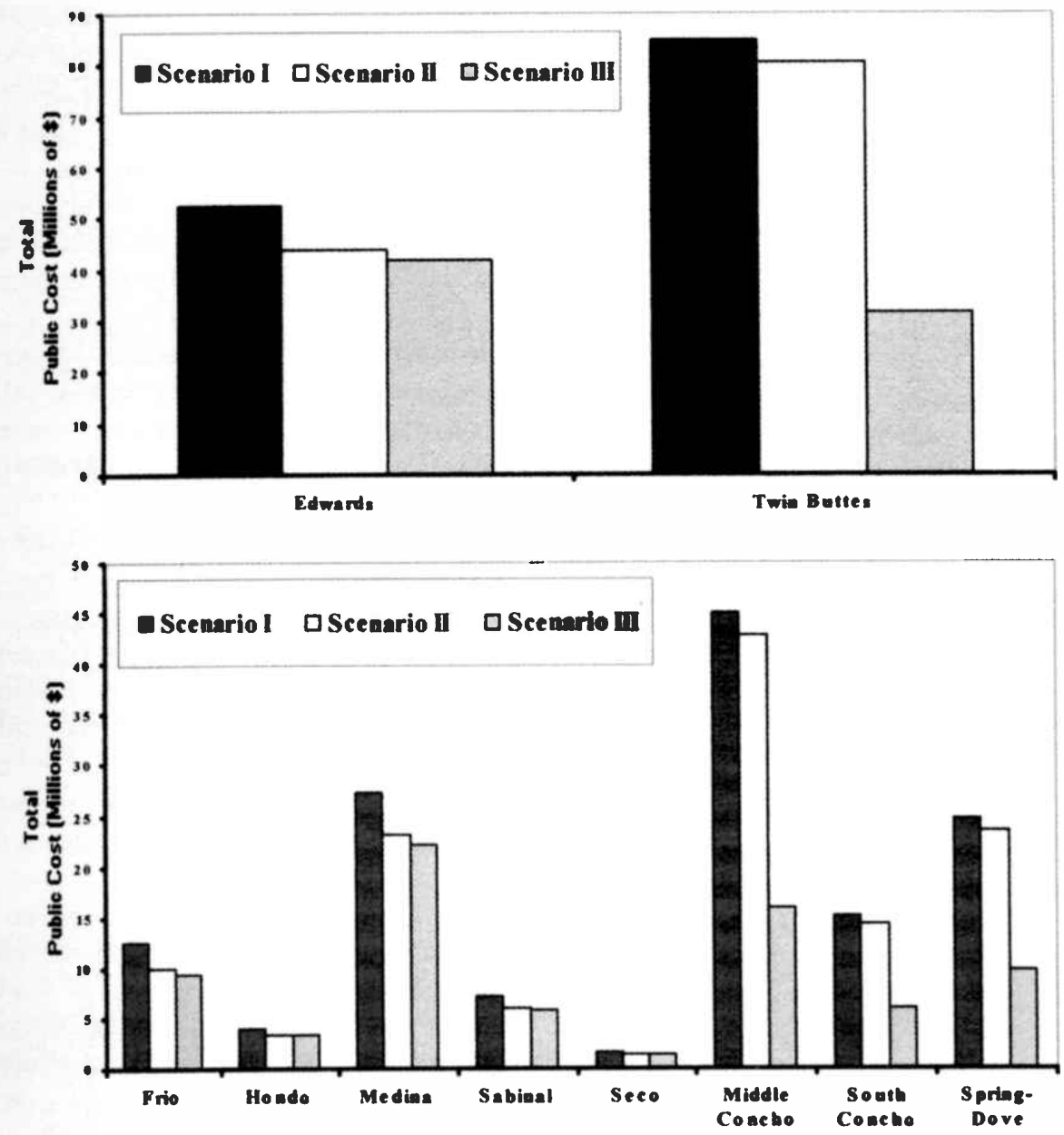

Fig. 3. Total public costs for Edwards and Twin Buttes watersheds and basins by brush treatment scenario.

From a water production efficiency perspective, the Edwards basins were found to be less costly per unit of added water than the Twin Buttes basins. The average cost of added water for the entire Edwards for all scenarios was $\$ 32$ per $1000 \mathrm{~m}^{3}$ of water added compared to $\$ 82$ for the Twin Buttes. Based on cost per unit of water yield, basins to prioritize within the Edwards would include the Hondo and Medina while the South Concho would be the most cost effective in the Twin Buttes. Within individual basins, all brush treatment scenarios showed similar cost of added water reflecting the assumptions used in the SWAT model.

The higher water production efficiency of the Edwards must be weighed against the water needs of each study area. The population growth trends for the 2 major cities relying on water produced from the Edwards and Twin Buttes differ substantially. The San Antonio area, which relies on Edwards Aquifer water, experienced a $20.5 \%$ increase in population from 1992 to 2002; the population of San Angelo, which relies on water from Twin Buttes cies seeking additional water should give serious consideration to providing public funds to support cost-share brush programs. However, uncertainty does exist with regard to estimates of water yield using models and assumptions regarding brush treatment costs and livestock/wildlife revenues and costs.

Success of each brush treatment scenario in improving off-site water yield and restoring rangelands depends on the willingness of landowners to participate. One reason why landowners may be reluctant to participate in the 3 scenarios is the perceived impacts to wildlife, especially white-tailed deer and associated hunting enterprises. Scenario III, which attempts to retain adequate brush cover for wildlife, may be a more satisfactory option for landowners with this concern than Scenarios I and II. Another reason for landowner reluctance is the importance of brush to property values. The top motives for the purchase of the majority of landholdings throughout the state are recreation followed by the desire for rural homesites (Wilkins et al. 2000), both of which tolerate a higher level of brush than livestock production. Agriculture and livestock production, which generally benefits from decreased levels of brush, is no longer the driving force behind property purchases that it once was.

Landowner surveys conducted by Narayanan et al. (2002) indicate that landowners in the Edwards Aquifer recharge zone watershed would be willing to include an average of only $49 \%$ of their moderate (10-30\% canopy cover) brush and $53 \%$ of their heavy (>30\%) brush in a brush management program while Twin Buttes' landowners who are more dependent on their land for production would be willing to include $59 \%$ of their moderate cover and $64 \%$ of their heavy cover. Because Scenarios I and II require the control of all moderate and heavy categories of mesquite, juniper, and mixed brush, the probability of landowners electing to implement these 2 scenarios would be low in both watersheds. With respect to Scenarios II and III, only $26.5 \%$ of survey respondents in the Edwards and $15.1 \%$ of respondents in the Twin Buttes said that requiring a 75 meter riparian buffer zone would either "reduce interest" or "prevent participation" in a program with that restriction, and approximately $71 \%$ of landowners in both study areas stated that the $40 \%$ brush constraint of Scenarios III would not change their interest. These 

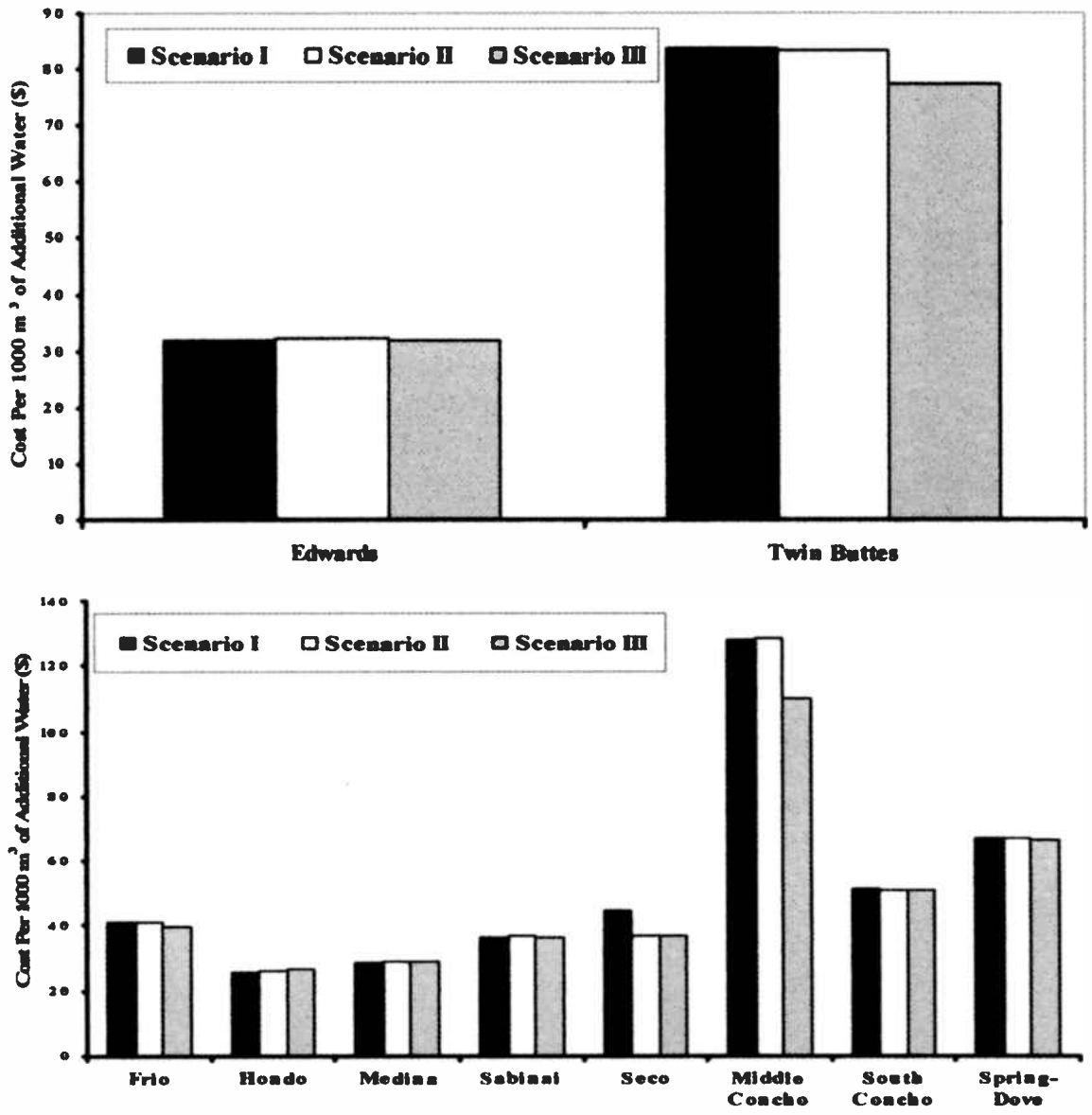

Fig. 4. Public cost of added water for Edwards and Twin Buttes watersheds and basins under each brush treatment scenario.

findings indicate that Scenario III may be the most attractive scenario to landowners in both watersheds.

Based on model predictions, Scenario III in the Edwards watershed would produce $80 \%$ of the water increase for Scenario I compared to only $40 \%$ in the Twin Buttes. The reluctance of landowners to enroll in high-impact programs based on parameters similar to Scenario I will not greatly hurt opportunities to produce water in the Edwards but may substantially suppress potential water yields in the Twin Buttes.

A chief concern with the implementation of brush control cost-share programs in the Edwards Plateau is the potential effects on federally-listed endangered species, specifically black-capped vireo (Vireo articapillus) and golden-cheeked warbler (Dendroica chrysoparia), which occupy distinct habitats. Golden-cheeked warblers utilize mature brush thickets with tall, closed canopies (Armstrong 2000). Because preferred deciduous trees for the golden-cheeked warbler are "usually associated with drainages, steeper slopes, and canyon areas" (Armstrong 2000) and gold- en-cheeked warblers tend to nest on sloped areas (Wilkins et al. 2002), brush treatment Scenarios II and III, which protect riparian areas and brush on slopes greater than $15 \%$, likely will not greatly impact golden-cheeked warbler populations. Black-capped vireo prefer open areas mixed with brush mottes (Armstrong 2000). This species utlizes land with $36-$ $55 \%$ canopy cover, but vegetation in preferred areas rarely exceeds $1.8 \mathrm{~m}$ in height (Gryzybowski 1995). To protect vireo habitat, brush control efforts targeting stands of low growing woody plants should be limited to areas not known to support vireo populations.

The added water yield data provided by the SWAT model shows a constant relationship between the amount of brush removed and water yield for nearly all basins. These results conflict with research conducted by Thurow and Hester (1997) which reports an exponential increase in water yield when brush cover declines from $15 \%$ to $0 \%$ so that substantial amounts of brush would need to be cleared to provide significant increases in water yield. It is possible that under Scenario III, where $40 \%$ of moderate and heavy brush is retained, increases in canopy and root growth of residual brush cover due to lower levels of competition may result in less added water than projected.

Costs not incorporated into the economic model include the transaction costs associated with implementing a cost-share program. These costs, including those associated with public hearings, contract development, and monitoring, would increase total brush program expenditures and are directly related to the number of participating landowners.

In addition, some aspects of the expected ecological changes provided by brush management and restoration treatments are difficult or impossible to quantify economically. For example, changes in nongame animal, aquatic wildlife composition, changes in recreational values of streams, and alterations of carbon sequestration capacity, should be considered in future studies.

Despite these limitations, our study provided a useful first approximation of the relative efficiencies of investing public funds in brush removal programs aimed at increasing water yield subject to retention of wildlife habitat and riparian areas. Future field studies are needed to more accurately quantify the effect of brush removal intensity on water yield and wildlife quality. Such knowledge will facilitate brush management trade-off analyses for future public fund investments.

\section{Literature Cited}

Armstrong, W.E. 2000. Results of "Ecosystem Management" on the Kerr Wildlife Management Area. p. 51-53. In: J. Cearley and D. Rollins (eds.) Proc. of the conf. on brush, water, and wildlife: A compendium of our knowledge. Texas Agr. Res. and Ext. Center. San Angelo, Tex.

Bach, J.P. and J.R. Conner. 1998. Economic analysis of brush control practices for increased water yield: The North Concho River example. In: R. Jensen (ed.) Proceedings of the $25^{\text {th }}$ Water for Texas Conference-Water planning strategies for Senate Bill 1. Austin, Tex.

Bach, J.P. and J.R. Conner. 2000a. Edwards Aquifer recharge zone watershed - economic analysis. p. 6:1-16. In: Brush management/water yield feasibility studies for eight watersheds in Texas. Tex. Water Res. Ins. College Station, Tex.

Bach, J.P. and J.R. Conner. 2000b. Twin Buttes/Nasworthy watershed - economic analysis. p.16:1-9. In: Brush management/water yield geasibility studies for eight watersheds in Texas. Tex. Water Res. Ins. College Station, Tex. 
Bednarz, S.T., T. Dybala, R.S. Muttiah, W. Rosenthal, and W.A. Dugas. 2000. Brush/water yield feasibility studies. p. 1:1-21. In: Brush management/water yield feasibility studies for eight watersheds in Texas. Tex. Water Res. Ins. College Station, Tex.

Blackburn, W.H. 1983 Influence of brush control on hydrologic characteristics of range watersheds, Brush manage. symp., Soc. For Range Manage. Meeting, Albuquerque, N.M. 73-88.

Conner, J.R. and J.P. Bach. 2000. Assessing the economic feasibility of brush control to enhance off-site water yield. p. 2:1-10. In: Brush management/water yield feasibility studies for eight watersheds in Texas. Tex. Water Res. Ins. College Station, Tex.

Dugas, W.A., R.A. Hicks, and P. Wright. 1998. Effect of removal of Juniperus ashei on evaporation and runoff in the Seco Creek Watershed. Water Resour. Res. 34:1499-1506.

Fulbright T.E.. 1997. Designing shrubland landscapes to optimize habitat for whitetailed deer. p. 61-67. In: D. Rollins, D.N. Ueckert, G. Brown (ed.) Brush sculptors: Innovations for tailoring brush rangelands to enhance wildlife habitat and recreational value. Tex. Ag. Ext. Serv. San Angelo, Tex.

Griffin, R.C. and M.E. Chowdury. 1993. Evaluating a locally financed reservoir: the case of Applewhite. J. Water Res. Planning and Manage. 119:628-644.

Gryzbowki, J.A. 1995. Black-capped Vireo (Vireo atricapillus). In: A. Poole and F. Gill (ed.) The Birds of North America. The Birds of North America, Inc. Philadelphia, Penn.

Hanselka, C.W., B.J. Ragsdale, and B. Rector. 1988. Grazing systems for profitable ranching. Tex. Agr. Ext. Serv. The Texas A\&M Univ. Syst. L-2211. College Station, Tex.

Lee, C.L., J.R. Conner, J.W. Mjelde, J.W. Richardson, and J.W. Stuth. 2001. Regional cost share necessary for rancher participation in brush control. J. Agr. and Res. Econ. 26(2)478-490.

Lemberg, B., J.W. Mjelde, J.R. Conner, R.C. Griffin, W.D. Rosenthal, and J.W. Stuth. 2002. An interdisciplinary approach to valuing water from brush control. J. Amer. Water Res. Ass. 38(2):409-422

Lesikar, B.J., B.L. Harris, and E.A. Hiler. 1998. Texas Agriculture Extension Service water supply and conservation education programs, p. 1-7. In: R. Jensen (ed.) Proc. of the $25^{\text {th }}$ Water for Tex. Conf. - Water planning strategies for Senate Bill 1. Tex. Wat. Res. Inst. Austin, Tex.

Narayanan, C.R., U.P. Kreuter, and J.R. Conner. 2002. Tradeoffs in brush management for water yeld and habitat management in Texas: Twin Buttes Drainage area and Edwards Aquifer recharge zone. Tex. Water Res. Inst. TR-195. College Station, Tex.

Rister, M.E., R.D. Lacewell, A.W. Sturdivant, J.R.C. Robinson, M.C. Popp, and J.R. Ellis. 2002. Economic and conservation evaluation of capital renovation projects: Harlingen irrigation district Cameron
County No. 1 - canal meters and telemetry equipment, impervious-lining of delivery canals, pipelines replacing delivery canals, and on-farm delivery-site meters. Tex. Water Res. Inst. TR-202. College Station, Tex.

Reinecke, R., J.R. Conner, and A.P. Thurow, 1997. Economic considerations in Ashe Juniper control. p. 6:3-10. In: Juniper Symposium Proceedings. Tech. Rep. 97-1, Tex. Agr. Exp. Sta. San Angelo, Tex.

Rollins, D. 2000. Integrating wildlife concerns into brush management designed for watershed enhancement. p. 38-46. In J. Cearley and D. Rollins (eds.) Proc. of the conf. on brush, water, and wildlife: a compendium of our knowledge. Texas Agr. Res. and Ext. Center. San Angelo, Tex.

Rollins, D., F.C. Bryant, D.D. Waid, and L.C. Bradley. 1988. Deer response to brush management in Central Texas. Wildl. Soc. Bull. 16:277-284.

Schumann, K., J.R. Conner, J.W. Richardson, J.W. Stuth, W.T. Hamilton, and D.L. Drawe. 2001. The use of biophysical and expected payoff probability simulation modeling in the economic assessment of brush management alternatives. J. Agr. and Appl. Econ. 33:539-549.

Tays, M.R. 2001. Factors influencing landowner willingness to enroll in a costshare brush management program in the Pedernales River Watershed, Texas. MS Thesis. Texas A\&M Univ. College Station, Tex.

TWDB (Texas Water Development Board). 1997. Water for Texas - A consensus-based update to the State water plan. Vol. II Tech Planning Appendix. Tex. Water Develop. Bd. Doc. No. GP-6-2. Austin, Tex.

TWDB (Texas Water Development Board). 2001. State water plan: Water for Texas2002. Dec. 2001

Thurow, T.L., and J.W. Hester. 1997. How an increase or a reduction in juniper cover alters rangeland hydrology. In: Juniper Symp. Tech. Report 97-1. Tex. Agr. Exp. Stn. San Angelo, Tex.

TSL (Texas State Legislature). 1997. Seventy-fifth legislature: Session logs. Chapter 10-10, pp. 3610-3791. Austin, Tex.

Upper Colorado River Authority. 2000. Concho River \& upper Colorado River basins: brush control feasibility study. www.ucra-tx.org.

Walker, J.W. and W.A. Dugas. 1998. Site selection for publicly funded brush control to enhance water yield. p. 199-208. In: R. Jensen (ed.) Proc. of the $25^{\text {th }}$ Water for Tex. Conf. - Water Planning Strategies for Senate Bill 1. Tex. Water. Res. Inst. Austin, Tex.

Welch, T.G. and J.S. Anderson. 1993. Seeding Rangeland. Tex. Agr. Ext. Serv. B1379. College Station, Tex.

Wilkins, N., R.D. Brown, J. R. Conner, J. Engle, C. Gilliland, A. Hays, R. D. Slack, and D.W. Steinbach. 2000. Fragmented Lands: Changing Land Ownership in Texas. Texas A\&M University. TR No. MKT-3443. The Agriculture Program. Texas A\&M Univ. College Station, Tex.
Wilkins, R. N., S.J. Hejl, D.R. Magness, and T.L. Bedford. 2002. Wildlife response to brush management. In: Ecosystem and wildlife implications of brush management systems designed to improve water yield. Tech. Report - 201. Tex. Agr. Exp. Sta. and Tex. Water Res. Inst. College Station, Tex.

Wilcox, B.P. 2002. Shrub control and streamflow on rangelands: A process based viewpoint. J. Range Manage. 55:318-326.

Whitson, R.E., L.B. Merrill, H.T. Wiedemann, and C. A. Taylor, Jr. 1984. Economic feasibility of brush control in the Edwards Plateau. Texas Agr. Exp. Sta. MP1554. College Station, Tex. 